\title{
Predicting the financial distress of Indonesian manufacturing companies: an application of the multinomial logit model
}

\author{
Jaja Suteja, Ardi Gunardi* \\ and R. Avianty Octavia \\ Faculty of Economics and Business, \\ Universitas Pasundan, \\ Jalan Tamansari 6-8 Bandung, 40116, Indonesia \\ Email: jajasuteja@unpas.ac.id \\ Email: ardigunardi@unpas.ac.id \\ Email: aviantyoctavia@gmail.com \\ ${ }^{*}$ Corresponding author
}

\begin{abstract}
This study aims to provide empirical evidence on the factors influencing a company's financial distress. This study examines the role of financial ratios attained from financial statements in predicting the financial distress of manufacturing companies listed in the Indonesia Stock Exchange from 2009 to 2011. The research sample consists of a group of 100 healthy companies, the group of negative net income companies that experience distress for two consecutive years consists of 14 companies, and the group of negative equity book value that experiences financial distress for two consecutive years consists of five companies. The multinomial logit regression was used to test the hypothesis. Results indicate that financial ratios attained from financial statements, namely, profit margin ratio, profitability, and financial leverage, are significant variables in predicting the financial distress of manufacturing companies listed in the Indonesia stock exchange.
\end{abstract}

Keywords: financial distress prediction; financial ratios; financial statements; multinomial logit; Indonesian manufacturing companies.

Reference to this paper should be made as follows: Suteja, J., Gunardi, A. and Avianty Octavia, R. (2017) 'Predicting the financial distress of Indonesian manufacturing companies: an application of the multinomial logit model', Int. J. Monetary Economics and Finance, Vol. 10, Nos. 3/4, pp.250-256.

Biographical notes: Jaja Suteja is an Associate Professor of Banking and Finance at Universitas Pasundan, Indonesia. He teaches strategic financial management, investment, banking and finance in both undergraduate and postgraduate programs. His research interests include banking, corporate finance, financial market and investment.

Ardi Gunardi received his Master in Management Science from Universitas Padjadjaran, Indonesia. He is a Lecturer of Finance at Universitas Pasundan, Indonesia. His research interests include financial markets, banking, and corporate social responsibility.

R. Avianty Octavia was graduated in Management Study Program from Universitas Pasundan, Indonesia. 
This paper is a revised and expanded version of a paper entitled 'Predicting financial distress of Indonesian manufacturing companies: an application of multinomial logit model' presented at SIBR 2015 Conference on Interdisciplinary Business and Economics Research, Hong Kong, 3-4 October, 2015.

\section{Introduction}

The recent economic crisis was caused by several problems. One of the unnoticed issues in the 2007-2009 global financial crisis was the liquidity risk resulting from the termination of a major participant in foreign or cross-border payment and settlement systems. That is, the announcement that Lehman Brothers, a leading global investment bank based in USA, had filed for bankruptcy on 15 September, 2008. This event increased the risks to any of its counter-parties to become illiquid (Cordey and Rossi, 2010). Indonesia was one of the countries that felt the shock of this crisis as many Indonesian companies were affected.

The changing business landscape to be more globalised and the competitive environment significantly affect all industries, including manufacturing companies. Large, medium, and small businesses are all affected by the change regardless of their orientation, whether profit or non-profit (Sunarni, 2013). Manufacturing companies are the largest by number listed in the Indonesia Stock Exchange. Some manufacturing companies in Indonesia also felt the impact of the global financial crisis, including the decreased production due to the plummeting demand. Eventually, sales were also affected.

Companies that continue to show a declining performance will likely experience financial distress that will lead them to the bankruptcy. Platt and Platt (2002) define financial distress as the decline phase of a financial condition that occurs prior to bankruptcy or liquidation. Thus, a predictive model must be developed to anticipate financial distress, and an early warning system for financial distress is also needed. This model can be used as a tool to identify and improve the condition prior to a crisis or bankruptcy.

Altman (1968) examines corporate financial distress by applying the multiple discriminant analysis (MDA) technique for failure classification model. Alexakis (2008) finds that the Altman model performs well in predicting failures for a period of up to five years earlier. Therefore, MDA has become widely used in corporate failure studies. However, MDA is limited because it assumes that all variables in the data sample are normally distributed (Ong et al., 2011).

Several studies have recently adopted a logit model to build a prediction model of financial distress to overcome some of the limitations of MDA and to provide greater prediction accuracy (Veronica and Anantadjaya, 2014; Nindita et al., 2014; Ahmad, 2013; Juniarti, 2013; Alifiah et al., 2013; Yap et al., 2012; Ong et al., 2011; Uğurlu and Aksoy, 2006). According to Uğurlu and Aksoy (2006), a logit model has a higher classification power and more accurate predictions than a discriminant model. Yap et al. (2012) consider logistic regression as an effective and reliable statistical tool.

Previous research has identified some gaps such as differences in the object of study, period of the study, variables that can differentiate the research findings, and 
inconsistency of findings in research on the same variable. These gaps are evidenced by several studies such as Veronica and Anantadjaya (2014), Nindita et al. (2014), Alifiah et al. (2013), Ahmad (2013), Juniarti (2013), Yap et al. (2012), Ong et al. (2011), Li and Sun (2011), Almilia (2006), Almilia and Kristijadi (2003), Abid and Zouari (2002) and Sulaiman et al. (2001).

The current study aims to develop a logit model using financial ratios derived from financial statements to predict the financial distress of manufacturing companies listed in the Indonesia Stock Exchange from 2009 to 2011. The motivation of this research is to determine if financial ratios derived from the financial statements published by the company can be used to predict the financial distress.

\section{Literature review}

\subsection{Financial distress}

Financial distress is a condition in which companies have bankruptcy potency because they cannot pay their need and make low profit (Nindita et al., 2014). It affects capital change and leads to companies being restructured. Analysing the financial problems can help companies to decide and take actions on companies having financial distress.

Platt and Platt (2002) define financial distress as a decreasing step in the financial condition that occurs prior to bankruptcy or liquidation. In this study, companies are grouped into those experiencing financial distress and have negative retained earnings and those experiencing financial distress and have net income in two sequential years (Juniarti, 2013). Thus, the companies performed various analyses of the possibility of bankruptcy.

\subsection{Financial ratio}

According to Brigham and Daves (2007), the signs of potential financial distress are generally evident in a ratio analysis before the firm actually fails. Researchers use ratio analysis to predict the probability of a firm going bankrupt. Thus, financial ratios are useful indicators of the financial performance condition of firms in the past, present, and future. Most financial ratios can be calculated from financial statements.

The indication of financial distress can be predicted by using financial ratios, such as liquidity ratios, leverage ratios, profitability ratios, and activity ratios as stated in Veronica and Anantadjaya (2014), Nindita et al. (2014), Alifiah et al. (2013), Ahmad (2013), Juniarti (2013), Yap et al. (2012), Ong et al. (2011), Li and Sun (2011), Almilia (2006), Almilia and Kristijadi (2003), Abid and Zouari (2002) and Sulaiman et al. (2001).

Veronica and Anantadjaya (2014) find the indicators of financial performance as measured by financial ratios and cash flow ratios results three years prior to bankruptcy. These indicators significantly affect the formation of a company's bankruptcy prediction model. In addition, the results show that the companies need to pay more attention to the current ratio, debt ratio, return on assets, total asset turnover, cash flow, and return on assets ratio because these indicators can predict a company's bankruptcy.

Nindita et al. (2014) reveal that the financial ratios of current ratio, cash ratio, and debt ratio have a significant effect on the prediction of financial difficulties. These ratios significantly affect the negative correlation coefficient in predicting company financial 
distress. Alifiah et al. (2013) find that the independent variables that can be used to predict a company's financial difficulties are debt ratio, total asset turnover, and working capital ratio.

Ahmad (2013) suggests that fundamental factors, such as return on assets and return on equity result in a negative coefficient and predict financial distress, whereas debt to equity ratio has a positive relationship and predicts financial distress.

Juniarti (2013) argues that net profit margin is the only variable that significantly differentiates a healthy company from a company with financial difficulties. Yap et al. (2012) reveal that financial ratio measuring liquidity is the most significant predictor of financial distress.

Ong et al. (2011) discover five financial ratios that are significant and useful for predicting distress among Malaysian firms. The financial ratios of current asset turnover, asset turnover, day sales in receivables, cash flow to total debt, and total liabilities to total assets can predict corporate failure.

$\mathrm{Li}$ and Sun (2011) indicate that short-time liabilities, profitability, and structural ratios are important in descending order to prevent companies from being distressed. Almilia (2006) states that the ratios from financial statements of income, balance sheets, and statements of cash flow are significant variables in determining financially distressed firms.

Almilia and Kristijadi (2003) explain that net profit margin, financial leverage ratio, current ratio, and growth are significant variables in determining a company's financial distress. Abid and Zouari (2002) show that sales growth and liability ratios contribute to the prediction of financial distress.

Sulaiman et al. (2001) reveal three factors that have significant discriminatory power: debt ratio, interest coverage, and total assets turnover. In their study, a logit model is used to accurately classify $80.7 \%$ of the companies in the estimation sample and $74.4 \%$ in the hold-out sample.

\section{Data and methods}

The sample in this research consists of manufacturing companies listed in the Indonesia Stock Exchange from 2009 to 2011. The companies are determined by purposive sampling method. Considerations in the determination of the sample are as follows:

- manufacturing companies listed in the Indonesia Stock Exchange in 2009 to 2011

- firms that published their financial statements in the 2009-2011 period

- companies classified into three groups: those that are not in financial distress, those that experienced a negative net income in two consecutive years, and those that experienced a negative equity book value in two consecutive years.

A total of 119 firms met these criteria.

Data analysis was performed using the multinomial logit model. This model is chosen because this study has a qualitative dependent variable and the response variable has three or more categories. The dependent variable is the financial distress conditions, which are categorised into three groups: group 1 are companies that are not in financial distress (proxied by 0), group 2 are companies that experienced a negative net income for 
two consecutive years (proxied by 1), group 3 are companies that experienced a negative equity book value for two consecutive years (proxied by 2 ).

\section{Results and discussion}

As shown in Table 1 , the number $-2 \mathrm{LL}$ at the beginning (intercept only) is compared with the number -2LL in the final model to assess the overall model fit. A decrease in value indicates that the model is a suitable regression model. This model shows the number $-2 \mathrm{LL}$ at the beginning model (intercept only) of 378.180 and the number $-2 \mathrm{LL}$ at the final model of 112.105. This result shows a decrease, and thus, this model can be concluded to be a suitable regression model.

Table 1 Results of multinomial logit regression testing

\begin{tabular}{|c|c|c|c|c|}
\hline & \multicolumn{2}{|c|}{ Group 1 vs. Group 2 and 3} & \multicolumn{2}{|c|}{ Group 2 vs. Group 3} \\
\hline & $B$ & Sig. & $B$ & Sig. \\
\hline Intercept & 13.310 & 0.005 & 8.225 & 0.073 \\
\hline Net profit margin & -14.928 & $0.009^{*}$ & -22.516 & $0.001 *$ \\
\hline Current ratio & -3.384 & 0.103 & -3.278 & 0.114 \\
\hline Total assets turnover & 3.027 & 0.124 & 2.307 & 0.227 \\
\hline Return on assets & 18.849 & $0.003 *$ & 5.107 & 0.365 \\
\hline Debt ratio & -11.669 & $0.000 *$ & -4.957 & $0.077 * *$ \\
\hline Cash ratio & 74.058 & 0.114 & 74.114 & 0.114 \\
\hline Growth sales & -1.497 & 0.332 & -2.111 & 0.190 \\
\hline-2 log likelihood (intercept only) & & 378 & & \\
\hline -2 log likelihood (final) & & 112 & & \\
\hline \multirow[t]{2}{*}{ Nagelkerke } & & & & \\
\hline & \multicolumn{2}{|c|}{ Number of observations } & \multicolumn{2}{|c|}{ Percentage (\%) } \\
\hline Classification power group 1 & \multicolumn{2}{|c|}{297} & \multicolumn{2}{|c|}{100} \\
\hline Classification power group 2 & \multicolumn{2}{|c|}{42} & \multicolumn{2}{|r|}{71.4} \\
\hline Classification power group 3 & \multicolumn{2}{|c|}{15} & \multicolumn{2}{|r|}{86.7} \\
\hline Total classification power & \multicolumn{2}{|c|}{354} & \multicolumn{2}{|c|}{96} \\
\hline
\end{tabular}

The test result of the multinomial logit regression in Table 1 indicates that the variables that can be used to classify group 1 into groups 2 and 3 are net profit margin, return on assets, and debt ratio. These variables are statistically significant at the 5\% level. Net profit margin and debt have a negative relationship and are statistically significant with the probability of the companies in groups 2 and 3 . That is, the higher the net profit margin and debt ratio are, the lower the probability of companies to be classified into groups 2 and 3. Return on asset has a positive relationship and is statistically significant with the probability of companies to be classified into groups 2 and 3. That is, the higher the return on asset is, the higher the probability of companies to be classified into groups 2 and 3. 
This research is consistent with that of Anantadjaya and Veronica (2014), which indicates that return on asset reflects that a company needs to pay attention to the actual use of total assets because the combination of total assets cannot generate enough revenue. Therefore, the company may not be efficient in utilising its assets in routine operations. The high return on assets shows that the company uses its assets more efficiently to generate profits. Conversely, a small value of return on assets indicates that the company is not efficient in utilising its assets. A low return on assets may put the company in financial difficulties, and the probability of bankruptcy is likely to increase over time.

The variables that can be used to classify group 2 into group 3 (Table 1) are net profit margin, which is statistically significant at the $5 \%$ level, and debt ratio, which is statistically significant at the $10 \%$ level. Net profit margin and debt ratio have a negative relationship and are statistically significant with the probability of companies to be classified into group 3 . That is, the higher these two ratios are, the lower the probability of companies to be classified into group 3 .

Net profit margin has negative relationship as supported by the research of Juniarti (2013) and Almilia and Kristijadi (2003), which indicates that net profit margin significantly differentiates a healthy company from one with financial difficulties. Debt ratio has a negative relationship and is statistically significant. This result is consistent with that of Nindita et al. (2014), Almilia (2006) and Sulaiman et al. (2001).

Table 1 presents the classification power for groups 1-3. The model indicates that company classification power in group 1 is $100 \%$, that in group 2 is $71.4 \%$, and that in group 3 is $86.7 \%$. The overall classification model has the power of $96 \%$. Thus, in terms of classification accuracy, the logit model is proven more accurate than other models in prediction. This finding is supported by Alifiah et al. (2013), Juniarti (2013), Yap et al. (2012), Ugurlu and Aksoy (2006) and Sulaiman et al. (2001).

The Nagelkerke value for this model is 0.805 , which means that the variability of the dependent variable explained by the variability of the independent variable is $80.5 \%$. This result is consistent with that of Veronica and Anantadjaya (2014), which indicates that the indicators of financial performance, as measured by financial ratios, contribute to the prediction model formation of a company's bankruptcy.

\section{Conclusion}

This study attempts to examine the classification power of financial ratios derived from financial statements to predict a company's financial distress by utilising the multinomial logit analysis model. The result of this study indicates that the model incorporating financial ratios derived from financial statements, namely, net profit margin, return on assets, and debt ratio, can be used to predict corporate financial distress. The total classification power of this model is $96 \%$. Thus, the logit model is still proven accurate in predicting a company's financial distress, and it is an effective and reliable statistical tool. 


\section{References}

Abid, F. and Zouari, A. (2002) 'Predicting corporate financial distress: a neural networks approach', Finance India, Vol. 16, No. 2, pp.601-612.

Ahmad, G.N. (2013) 'Analysis of financial distress in Indonesian stock exchange', Review of Integrative Business and Economics Research, Vol. 2, No. 2, pp.521-533.

Alexakis, P. (2008) 'Altman Z-score model' and prediction of business failures and prediction of business failures', Int. J. Monetary Economics and Finance, Vol. 1, No. 4, pp.329-337.

Alifiah, M.N., Salamudin, N. and Ahmad, I. (2013) 'Prediction of financial distress companies in the consumer products sector in Malaysia', Jurnal Teknologi, Vol. 64, No. 1, pp.85-91.

Almilia, L.S. (2006) 'Prediksi kondisi financial distress perusahaan go-public dengan menggunakan analisis multinomial logit', Jurnal Ekonomi Dan Bisnis, Vol. 12, No. 1, pp.1-26.

Almilia, L.S. and Kristijadi (2003) 'Analisis rasio keuangan untuk memprediksi kondisi financial distress perusahaan manufaktur yang terdaftar di bursa efek jakarta', Jurnal Akuntansi Dan Auditing Indonesia, Vol. 7, No. 2, pp.183-210.

Altman, E.I. (1968) 'Financial ratios, discriminant analysis and the prediction of corporate bankruptcy', The Journal of Finance, Vol. 23, No. 4, pp.589-609.

Brigham, E.F. and Daves, P.R. (2007) Intermediate Financial Management, 9th ed., Thomson South-Western, Mason.

Cordey, P-A. and Rossi, S. (2010) 'Financial stability needs global time', Int. J. Trade and Global Markets, Vol. 3, No. 2, pp.217-229.

Juniarti (2013) 'Good corporate governance and predicting financial distress using logistic and probit regression model', Jurnal Akuntansi Dan Keuangan, Vol. 15, No. 1, pp.43-50.

Li, H. and Sun, J. (2011) 'Mining business failure predictive knowledge using two-step clustering', African Journal of Business Management, Vol. 5, No. 11, pp.4107-4120.

Nindita, K., Moeljadi and Indrawati, N.K. (2014) 'Prediction on financial distress of mining companies listed in BEI using financial variables and non-financial variables', European Journal of Business and Management, Vol. 6, No. 34, pp.226-236.

Ong, S.W., Yap, V.C. and Khong, R.W.L. (2011) 'Corporate failure prediction: a study of public listed companies in Malaysia', Managerial Finance, Vol. 37, No. 6, pp.553-564.

Platt, H.D. and Platt, M.B. (2002) 'Predicting corporate financial distress: reflections on choice-based sample bias', Journal of Economics and Finance, Vol. 26, No. 2, pp.184-199.

Sulaiman, M., Jili, A. and Sanda, A.U. (2001) 'Predicting corporate failure in Malaysia: an application of the logit model to financial ratio analysis', Asian Academy of Management Journal, Vol. 6, No. 1, pp.99-118.

Sunarni, C.W. (2013) 'Management accounting practices and the role of management accountant: evidence from manufacturing companies throughout Yogyakarta, Indonesia', Review of Integrative Business and Economics Research, Vol. 2, No. 2, pp.616-626.

Uğurlu, M. and Aksoy, H. (2006) 'Prediction of corporate financial distress in an emerging market: the case of turkey', Cross Cultural Management: An International Journal, Vol. 13, No. 4, pp.277-295.

Veronica, M.S. and Anantadjaya, S.P.D. (2014) 'Bankruptcy prediction model: an industrial study in Indonesian publicly-listed firms during 1999-2010', Review of Integrative Business and Economics Research, Vol. 3, No. 1, pp.13-41.

Yap, B.C.F., Munuswamy, S. and Mohamed, Z.B. (2012) 'Evaluating company failure in Malaysia using financial ratios and logistic regression', Asian Journal of Finance and Accounting, Vol. 4, No. 1, pp.330-344. 